\section{Research in India}

IT is only natural that Dr Macdonald (Nature, November 15, 1974)-with his World Health Organisation (WHO) and Genetic Control of Mosquito Unit (GCMU) connections-should have reacted the way he has, to a part of my item on work on the genetic control of mosquitoes (Nature, September 20, 1974). I am afraid I cannot agree that there was anything "misleading", "misinformed" or "erroneous" in statements which pointed out disparities between population needs and the GCMU's priorities in choosing its programmes. The military implications too cannot be summarily dismissed, as Dr Macdonald has done, by merely hiding behind the familiar generalisation that all research results, in theory, could be misused. The fact of the matter is that there have been instances of misapplications. It may well be recalled that the defoliants employed by the US Army in Vietnam were reported to have been first tested for their effects in some Latin American countries. I cannot say what were the specific long-term benefits from these tests to the Latin American Communities.

Then there is the case of childhood malnutrition. For years now, we have been led to believe (by all kinds of agencies including UN and others) that protein deficiency in the Indian diet is the major cause of malnutrition in India. Consequently, vast amounts of Indian (as well as foreign) money were diverted towards high-protein food programmes, whereas the problem all along-we are now told-has been one of simply not enough food.

Moreover, studies "specifically designed for the long-term benefit of the community" should surely be able to stand a little scrutiny, and a probe into the whole affair can only result in clearing the air and, I hope, lend support to contentions like $\mathrm{Dr}$ Macdonald's, and I and many others in the scientific community shall be happier for it. Little inconveniences like these, I am afraid, will remain a foreign scientist's lot (not only in India but elsewhere) so long as instances of the academic and scientific communities providing cover for nefarious activities by their governments continue to surface.

Yours faithfully,

NARENDER K. Sehgal

\section{Jullundur}

Sir,- The belated comments on United States Defense Department and National Museum activities in India by N. K. Sehgal and A. N. D. Nanavati (Nature, September 20, November 29) need to be considered in relation to some other past history.

So far as I can make out the most revealing information is provided by William E. Small in Scientific Research (3, (25), 27; December 9, 1968), where investigations of bird diseases transmissible to man in Brazil and the biology of the north central Pacific by the Smithsonian Institution (the US National Museum) were identified as supported by the US Defense Department chemical and biological (CB) warfare research centre at Fort Detrick in Maryland. The resulting furore reached a climax the following February, as reported in the Washington Post and New York Times on February 5 and the London Times and Guardian next day, where it is alleged that Baker Island in the central Pacific had been chosen for tests. Eventually President Nixon announced on November 25, 1969 that the USA would abandon CB warfare except for a small defensive programme, though the Times reported on September 21, 1971 that stocks of tularaemia, anthrax, $Q$ fever and Venezuela equine encephalitis organisms were retained and work continued at Dugway, Utah, the place where 6,000 sheep were inadvertently killed in a mismanaged nerve gas experiment in March 1968.

Although this activity may suggest that the US Defense Department, in collaboration with the Smithsonian Institution, also financed a Migratory Animal Pathological Survey from Korea through the Far East and India to the eastern Mediterranean at much the same time, as far as one can make out the actual work was normally delegated to irreproachably upright citizens who succeeded in making very good use of the funds provided, to such an extent that the people most likely to take offence, the Russians (who were incidentally carrying out similar activities of their own), were happy to cooperate, as reported by $\mathrm{Mr}$ Nanavati, though the Chinese refused to do so. In consequence the withdrawal of US funds following criticism of the Defense Department has resulted in a sad gap in ornithological work in the Far East especially, where one could wish for a less controversial alternative source of money. Mr Sehgal may rest assured that whatever the original object of the Migratory Animal Pathological Survey, a lot of people have scrutinised its activities rather carefully and found nothing to complain about except some roughness in handling captive birds, so that many of us who were once among the foremost critics of its possible original object would now like to see some means found to keep it in being.

As many people have already remarked, it also seems a pity that the
Smithsonian Institution ever allowed its activities to become so closely associated with those of the US Department of Defense, and it hardly seems surprising that people in India remain suspicious.

$$
\begin{aligned}
& \text { Yours faithfully, } \\
& \text { W. R. P. BouRnE }
\end{aligned}
$$

University of Aberdeen

\section{Ghost families}

SIR,-There are even families of ghost writers (December 6). Proc 5th int. Conf. Soil Mech. (1961) lists in its Author Index not only F. Asce (II, 105) but also his more prolific younger brother M. Asce (I, 517 and II, 117). Is there a case for forming a Society of Irreproducible Scientific Authors?

Yours faithfully,

Philip I. LeWIN

Building Research Station,

Garston, Watford, UK

SIR,-May I add to the Christmas season of 'ghost authors' with my own favourite. A paper on a mermaid foetus is quoted in the Cumulative Index Medicus, and also by at least one subsequent author, as Williams, H. I., and Lumpur, K, (1962) Arch. Path. (Chicago), 74, 472. In fact reference to the paper itself shows that Dr Williams, the sole author, wrote his report from Kuala Lumpur.

$$
\begin{aligned}
& \text { Yours faithfully, } \\
& \text { MARTIN d'A. CRAWFURD }
\end{aligned}
$$

The University,

Leeds, UK

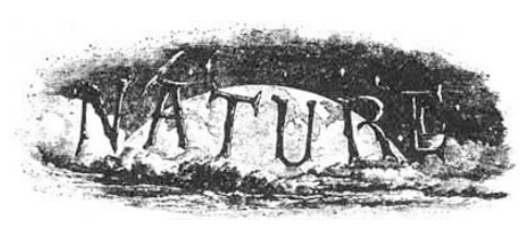

\section{A hundred years ago}

THE great solar eclipse of 1868 was visible in Siam, as the 1875 eclipse will be. The then reigning Siamese king had not invited any European astronomer; but the French Government sent an expedition, who located themselves in Malacca for the purpose of taking spectroscopic observations. The King of Siam, who professed to be an astronomer, came with a royal train and a large army to observe the sun and perhaps the sun-observers. The observations were very successful indeed; but the French astronomers had located themselves on marshy land and were almost all attacked by fever, of which they were cured only on their return to France. Such was not the case, however, with their royal guest, who was also attacked, and died a few months afterwards.

from Nature, 11, 216, January 14, 1875 